\title{
Ciprian Negoiță
}

\section{FROM THE CONCEPT TO THE PRACTICE OF PARLIAMENTARY IMMUNITY ${ }^{1}$}

DOI: $10.1515 /$ ppsr-2015-0021

\begin{abstract}
Scholars have long debated the normative rationality, the temporal and legal aspects, and finally the limits and modern practices of parliamentary immunity. Therefore, this study does not insist on these classical interpretations anymore, but seeks to contribute to a comprehensive understanding of the conceptual history of parliamentary immunity. Embracing two schools of thought, the Koselleckian interpretation and the Skinnerian variant, this paper aims to establish and clarify in detail the story of the concept of parliamentary immunity in order to elucidate, in a Socratic fashion, what we really mean when we say that a senator or a deputy benefits from legislative immunity. This inquiry will help us emphasise how this concept leaves behind its abstract notion and becomes an institution with strict rules and practices. In addition, considering the importance of this concept in the modern legislative and rhetoric histories and the frequency with which it is used, this study will question the meanings of parliamentary immunity in the light of different historical settings and will eventually trace out a single, coherent, and unified conceptual matrix. My contention is that once parliamentary immunity - seen as a conceptual construct only adjusting the balance of power between the executive and the legislative powers - becomes an institution with strong practices, it enforces the parliament as a unified and independent body and creates the prerequisite conditions for the democratic development.
\end{abstract}

Keywords: parliamentary immunity, king, parliament, democracy, conceptual history, Reinhart Koselleck

\section{Introduction}

To undertake an inquiry into the nature of the concept of parliamentary immunity, one must be aware of its act of conceptualisation. Like any other political concept, parliamentary immunity, without being an exception, is merely a small part of a larger conceptual and historical context, which in our case could be the birth and re-birth of parliamentarism. Immunity, by hypothesis, is a quality/condition of someone being immune or more precisely the ability to resist to an outside threat (Collin 2005, 191). When this kind of interpretation occurs in connection to a parliament (Murray 1909, 485) and "with respect to the universal and particulars of political nature" (Steinberger 1993, 7), we are then entitled to define this process as parliamentary immunity.

On these grounds, in order to understand parliamentary immunity, we must pursue in depth the term "immunity", which is an analysis that requires a Koselleckian interpre-

1 This paper is supported by the Sectoral Operational Programme Human Resources Development (SOP HRD), financed from the European Social Fund and by the Romanian Government under the contract number POSDRU/159/1.5/133675. 
tation of the differences in a temporal index (Palonen 2002, 91). From its birth into Latin and until the Middle Ages, the term managed to acquire different meanings, all of them being inseparable from the public and political spheres. The word designated throughout the Roman world, privileges granted by the emperor to different categories of people, the liberty to act without any constraints, or just simply an exception from taxes (Smith 1882). From the Late Middle Ages until the Enlightenment, immunity has been used with its feudal meanings, borrowing the Latin form and designating the exemptions from taxes for different categories of people (e.g., clergymen, priests, monks, nobles) and territorial immunity granted, in most cases, by the king to some properties or institutions (e.g., particular feuds, churches, monasteries). Soon after its entrance into national languages, the term immunity kept only its feudal meanings, until it was affiliated, as most historians would say by paradox, to a parliament. The closer we get to the mid-Modern period, the more the concept, through its nature, becomes intimately linked to the ideas of liberty, freedom of speech, sovereignty, representation, and separation of powers. For this reason, a conceptual analysis of parliamentary immunity requires a wide variant of notions to be considered at the same time. From the end of the Modern Period until the present day, the use of the concept expanded rapidly, not only in the academic sphere, but also in the political rhetoric of parliamentary elites.

By looking at these seminal ideas, we could easily annex parliamentary immunity to the idea of democratic development. Doubtless, it was democracy that shaped the contemporary meaning of the term and transformed it into an indicator of parliamentary life. Does the relation between immunity and democracy go back to a specific moment in time, before the entrance of this problematic concept into national languages? Among many other aspects this paper seeks to disclose, arguing about the interdependence between democracy and modern conceptualisation of parliamentary immunity is essential.

Today, parliamentary immunity is a significantly and widely used concept by academia and legal practitioners. The association of the concept with some sort of privileges creates a negative consideration of its limits, and due to the lack of understanding of its use, citizens tend to perceive it as a negative concept. Parliamentary immunity, the concept or the institution, should not be mistaken with the idea that one is above the law. Nobody has ever wanted this to happen. This assumption could be highlighted depending on particular variables such as space, political regime, and epoch, which favoured development of the concept. Without a doubt, legislative immunity does not imply the above the law principle, as it protects the parliament - the central institution of modern representative democracy - and not the parliamentary elites (Hardt 2013, 1).

This study was undertaken to firstly design the genealogy of the concept of parliamentary immunity from its time and place of birth in Latin until the present day, in the interest of providing a comprehensive account of its meanings, usages, and practices, avoiding as much as possible this concept misformation (Sartori 1970, 1033). Second, taking into consideration the English and French traditions of understanding parliamentary immunity, this paper will seek to evaluate the intimate engagement with democracy by examining different representative historical circumstances for this linkage. 


\section{Methodological challenges}

The core methodological and theoretical structures are specific to what Reinhart Koselleck famously defined in the German language as Begriffsgeschichte, or conceptual history. By using specific methods of inquiry advanced by the German approach of conceptual history (historical and critical analysis, theory development, diachronic contextualisation, and literature review), this article will investigate the evolution of the concept of parliamentary immunity in order to understand how immunity - which in one part of its history represented a privilege granted by the monarch to noblemen, landowners, clergy, and his close advisers - transformed at the end of 18th century into a democratic institution with strong practices deeply rooted in the parliamentary tradition that protects the independence and integrity of the parliament. A Koselleckian approach towards a particular political and social concept focuses on the innovations in meaning and linguistic shifts for the purpose of describing and explaining periods of crisis, which can sometimes accelerate a radical change in the meaning of a concept (Richter 1995, 10-11). This is also the case of parliamentary immunity. As we will later see, its original and pre-scientific meanings will suffer great shifts during the Glorious Revolution of 1689 and the French Revolution of 1789.

One could argue in favour of other conceptual approaches, either the one advanced by A. O. Lovejoy and his colleagues from the United States, or by the Cambridge School of Thought with its advocates such as Quentin Skinner, J. G. A. Pocock, and others. In fact, as Richter argues in his book The History of Political and Social Concepts. A Critical Introduction, the working methods advanced by Cambridge School of Thought, (for example historical investigation of political vocabularies, deconstruction of the political discourse, ideologies, and language) and Begriffsgeschichte seem to be compatible with one another, despite the fact that both projects experienced different national and political practices (Richter 1995, 124-143). Therefore, as I see it, even though it is not a simple task to put together two different methods of inquiry, I consider it important to use both approaches for following reason: on the one hand Reinhart Koselleck's working methods - main methodological principle - will guide our historical inquiry into the nature of parliamentary immunity, and on the other hand, Skinner's methods will help us analyse the classical modern interpretation of immunity as well as the parliamentary debates that marked the evolution of parliamentary privileges

\section{The origins of (parliamentary) immunity}

As Quentin Skinner - a respectable figure in the field of recent modern history - stresses in his intellectual inquiries that "concepts have only histories", ${ }^{2}$ we notice that parliamentary immunity is perceived in the eyes of scholars as a core concept in political science,

2 The idea that concepts only have histories was firstly used by Quentin Skinner in an interview from 23 November 2007 with Emmanuelle Tricoire and Jacques Lévy for EspacesTemps.net. See full interview at: http://www.espacestemps.net/en/articles/quentin-skinner-ldquoconcepts-only-have-historiesrdquo-en/ 
acquiring an array of meanings until its entrenchment in parliamentary life. Thus, when constructing the genealogy of parliamentary immunity, one must firstly look at two components: immunity, on the one hand, and parliamentary, on the other. Both words had a different historical-minded approach and, when the parliament was established, they blended - by paradox - forming together the concept of parliamentary immunity.

Immunitas-atis, the Latin form of today's immunity, had a number of meanings throughout the Roman world. The classic texts of Suetonius (1914, 62-85), Caesar (1917, 336), Cicero (1938, 61-253) and Titus Livius (1857, 319), as well as Latin dictionaries, revealed that immunitas experienced different meanings, from the exemption from taxes and military burdens and freedom from different services, to privileges acquired by a small part of society (e.g., clergy, nobility). These interpretations regulated the public life and created a division between social positions. In Ancient Rome, closer to what parliamentary immunity means today, were the special privileges owned by the tribunes so they could act freely and without any inconvenience. They were considered to be sacred, and in this way gained special protection against any sort of attack or obstruction (Hust 2000, 63). Such meanings that previously emerged in Latin, continued to be used during the 13th and 14th centuries in English and French, and later on in everyday languages.

\section{Privilege and immunity. The mark of two models}

Reviewing the literature regarding parliamentary immunity, we noticed that the historical evolution of the concept does not have a linear interpretation. In fact, as far as our research goes, there are two most common models of parliamentary immunity that predominate the medieval and modern parliamentary practice regarding this privilege. The first, specific to most Westminster systems, has an English origin and was created with the purpose of offering integrity, independence, and authority, while defending parliamentarians from the authoritarian rule of the monarch (Macreadie \& Gardiner 2010, 12). The second, the French continental model of immunité, specific to parliamentary privileges of continental Europe - partially influenced by the English model - managed to acquire within the context of the French Revolution of 1789 a broad interpretation with its two-fold features of non-liability and inviolability. Since their adoption, the two models continued to greatly influence the evolution of parliamentary immunity, each on its particular parliamentary systems.

The English model of immunity preserves the Latin meaning of privilege ${ }^{3}$ and refers to a special status owned by the representative within the Westminster parliament and "the law governing the British parliamentary affairs" (Hardt 2003, 56). As the legislative formation of the Westminster parliament could be called the first fully fledged parliament ever created and was considered a source of inspiration for other legislative institutions, such

3 The term privilege is the English equivalent of parliamentary immunity and has its roots in the Latin privilegium- $i$, n. privus-lex, the meanings of which designate a bill or a law in favour of an individual or a class. Taken separately, the noun privus-lex explicitly means someone/something that is separate or apart from the law. 
as Reichstag (Germany) and Duma (Russia), Riksdag (Sweden) and Storting (Norway), and Sobranie (Macedonia) (Pollard 1920), "parliamentary privilege" entered English vocabulary of the political spectrum earlier than it did in other European countries. Erskine May's Treatise on The Law, Privileges, Proceedings and Usage of Parliament, offers us a comprehensive definition of parliamentary immunity stating that the special status is a sum of rights enjoyed by both of the Houses collectively as a component part of the High Court of the parliament (Hardt 2013, 56). Here too, the evolution of English parliamentary immunity was marked by some historical circumstances that shaped many of today's practices and traditions regarding the special status of parliamentarians. In the very early phases of parliamentary history, only the House of Lords enjoyed, de iure, "their privileges simply because of their immemorial role in Parliament as advisers of the Souverain". Regarding the privileges of the House of Commons, they gradually evolved in an entangled historical process that also marked the evolution of the freedom of speech, freedom from arrest, and freedom to access to His Majesty whenever occasion shall require (May 2004, 77-78). This being said, when discussing English privileges, we will focus only on the privileges owned by the representatives of the House of Commons.

The earliest recorded historical moment that could be bound with the emergence of immunity is the case of Sir Thomas Haxey. In 1397, as a member in the House of Commons, he criticised King Richard II in a petition denouncing the high expenses and burdens of the Royal Court. Consequently, at the order of the king, Haxey was put on trial, deprived of his title and belongings, and sentenced to death (Hardt 2013; May 2004, 79; Gillespie 1997). Therefore, by the end of the 14th century, the parliamentary privilege of the Commoners was more a prescriptive issue than a principle rooted in the tradition of parliament. Another example that we came across is the case of Sir Thomas More who, in 1523, argued in favour of the freedom of speech as a "part of an ancient order" (May 2004, 80). Later on, both under the reign of Elizabeth I and King Charles I, the privilege of freedom of speech of the House of Commons continued to be under the influence of the monarch. An illuminating example in this direction are the cases of Sir John Elliot, Denzil Holles, and Benjamin Valentine - Commoners who were accused and sentenced by the king for seditious comments addressed to the Royal Court inside the House of Commons (May 2004, 80). The comprehensive form of this type of privilege took a legal form in 1689 when Article 9 of the Bill of Rights established freedom of speech as an undisputed institution.

Regarding the freedom from arrest, which is also a part of the Anglo-Saxon model of immunity, history shows that this privilege has also undergone transformations, the actors of which were the Commoners, the House of Lords, and the king. Although, freedom from arrest and molestation was - more in theory and less in practice - an early parliamentary tradition dating back to the foundation of Curia Regis, the political struggle of representatives of the House of Commons to enforce it as a legal institution was hard to win. The logic behind this type of immunity is that representatives should not be disturbed by any outside threat or action in continuing their activity. Richard Cheddar (1404), a servant of the House of Commons and the Speaker Sir Thomas Thorpe (1452), who were imprisoned at the order of the House of Lords to prevent them from attending sessions of parliament, 
represent relevant examples of why parliamentary immunity was needed in a democratic system. Along with the Parliamentary Act of 1770 and the Judgment Act of 1838, freedom from arrest and molestation changed dramatically, becoming marginalised and limited (Hardt 2013, 67). Finally, the freedom to access to His Majesty represented a privileged bestowed not by each individual member of parliament, but by the House of Commons as a unified institution represented by the Speaker. Unlike the freedom of speech and arrest, this particular privilege dismisses the monarch from taking part in debates and speeches of the members of the House.

The origins of the English model of privileges, as it was analysed above, indicate us that immunity was conceived around the ideas of freedom of speech (irresponsibility), freedom from arrest and molestation (inviolability), and freedom to access to His Majesty, principles that were gained by the House of Commons in their political confrontation with the authoritarian rule of the monarch (Griffith 1997, 2007, 2009). However, in Commentaries on the Laws of England, William Blackstone naturally argues that "immunity and other privileges were derived from parliament's original function as the High Court", in contrast to the idea of protecting the Commoners from the intrusion of the House of Lords and the Crown. Looking back at the historical evolution of parliamentary immunity and particular cases showing its importance, one might firmly tend to disagree with Blackstone's perspective. Hence, the conceptual pattern of parliamentary immunity in these particular cases has its own historic model of approach because of its early usage in connection with parliament and its distinct practices arising in the political and legal struggle for independence and liberty between the authoritarian rule of the monarch and the House of Commons.

In contrast, the origins of the French model of immunité parlementaire are closer in time than the English model. Although it preserved some characteristics of the Anglo-Saxon model, the political and constitutional reality and the parliamentary practice after the revolution of 1789 offered a broad interpretation of parliamentary immunity, which implies that "non-liability is much more absolute, while inviolability is open to exemptions and can be lifted by parliament itself" (Report, Venice Commission 2013). Even though the starting point of the analysis is the French revolutionary National Assembly of 1789, there are some preliminary remarks regarding the term immunity to be considered before the revolutionary moment.

In the French-speaking world, the term immunité, before being translated into parliamentary life, had its own entangled history which is worth telling in order to understand its act of conceptualisation. As far as our research goes, the term appeared in French in 1276 (Bloch 2004) meaning "safety". Later in the 14th and 15th centuries ${ }^{4}$ and until the 18th century, it acquired different interpretations similar to Latin ones, designating privileges or exemptions possessed by particular social classes, such as the French nobility,

${ }^{4}$ The evolution of the word immunité in France underwent a gradual examination. Using a particular method also embraced by the German historian Reinhart Koselleck, this study used different lexica and dictionaries such as: Dictionnaire étymologique de la langue française (2004), Le Grand Robert de La Langue Francaise, I,II edition (2001) and Dictionnaire de l'Académie française (1986). 
magistrates, public officers, and even high officials of the Church and monasteries (Rein 2001). Once the Old Regime was dismantled and the authority of the monarch reduced (Tocqueville 1856), the word immunity left aside its feudal meanings and started borrowing some particular practices from British custom of privileges born in the 14th century. Despite its long and entangled history, once the linguistic and institutional encounter was possible, both immunity and parliament were transferred at the same time into the dimension of political enterprise.

Under the Ancien Régime, as we could not speak about a fully-fledged parliament, but more of a proto-parliament represented by États Généraux, members of this institution were not given much immunity, as the king, through his lettre de cachet, could enforce and arrest any person at his personal will. Briefly, the privileges of the members of États Généraux under the Ancien Régime were only used to delay trials, as "the role and function of General Estates were closely bound up with the royal person and the legitimation of parliamentary rule derived exclusively from the king" (Manow 2010, 48). Later on, the revolution of 1789 and the development of the National Assembly represent the genuine historical starting point that triggered the parliamentary immunity build-up in France and later in other countries in Europe that adopted the French model. Through the voice of Honore Gabriel Riqueti, comte de Mirabeau, the principles of irresponsibility and non-liability/inviolability of deputies were established by Les Décrets des 23 juin 1789 et 26 juin 1790, thus ensuring the protection of representatives of the nation from the arbitrary rule of Louis XVI. The case of Marshall Pierre-Joseph de Toulouse-Lautrec, deputy in the National Assembly, who was arrested by the authorities of Toulouse on the grounds of taking part in counter revolutionary activities, represents another example of why inviolability was needed. Thus, as Louis XVI had not yet been sent to trial and his body politic could still exercise great influence over the state institutions, it was the fear of Executive's authority that formed the two layers of the French immunity system (Hust 2000; Hardt 2013).

In French constitutional practice, parliamentary immunity was firstly added to the Constitution of 1791, art. 7-8, mentioning explicitly that "the representatives of the nations were inviolable, and they could not be questioned, accused or trialled at any time for what they have said, written, or done in the performance of their duties as representatives and in case of criminal acts they may be seized flagrante delicto, or by virtue of a warrant of arrest". It seems that the first interpretation of the immunity with its two pillars - non-accountability (art. 7) and inviolability (art. 8) - brought by Mirabeau's two decrees, entered into the collective mind and practice of the constitutional architecture. Subsequently, future constitutional provisions regarding parliamentary immunity varied considerably, but the principle of two-tier immunity continued to dominate parliamentary practice.

Both the Anglo-Saxon model and the French model, signal a new shift towards democratic rule, when the members of parliaments in both of systems started to emancipate themselves from the king. Thus, it appeared inevitable that some preliminary observations should be made before engaging in analysis of the practice of parliamentary immunity. 


\section{The philosophical foundations of parliamentary immunity}

As Carl Schmitt famously claims in Crisis of Parliamentary Democracy, "defending parliament's capacity to work and function" deserves special attention, as it is difficult to offer a comprehensive explanation (Schmitt 2008). Parliamentary immunity as a conceptual construct created the conditions for the separation of powers (which was for Montesquieu, in his Esprit des Lois (1748), the basis of immunity law), strengthened and defended the role and independence of elected representatives (Manin 1997), and protected the human rights and the rule of law. All of the ideas attached to parliamentary privileges are thus expressions of the newly democratic system that appeared after the body politic of the monarch was replaced by the people (Kantorowicz 1997). How exactly and why are the members of the parliament immune from prosecution? To answer this question, we must look back at the essence of parliamentary immunity: the confrontation between the king and parliament, that is to say, between the Executive and the Legislative. We have two options: (1) we can accept, like Erskine May and other scholars, that somehow paradoxically, immunity transferred its meanings and implications from the ordinary law of the land to parliamentary life; (2) we can look closer, even philosophically, at how symbolically the sanctity and inviolability of the king were transferred to the nation and then to the representatives. Therefore, in this part of the study, we will try to demonstrate that the immunity of the members of the parliament is an imitation of the embodiment of the king's sacredness to people.

\section{"The King is dead, long live the King" vs. "The King is dead, long live the Republic"}

Both these two quotations contain cryptic interpretations of the two models of parliamentary immunity. The first represents the actual interpretation of the English model of privileges, where parliamentary immunity is still tied even today to the king, even though "the House of Commons executed the king's body natural in the name of the king's body politic" (Kantorowicz 1997, 21). The second is the French continental model, where along with execution of the physical body of the king, his sacredness and inviolability were confiscated by parliament. That is to say, in the first case, parliament consolidated its power and independence, "but was unable to suppress the natural body of the king after it had largely taken over his political role" (Manow 2010, 33). This was the consequence of the agreement from 1688 between the king and the House of Commons, which, one year later, gave the legal form of the privilege of freedom of speech. Subsequently, back in the days when the monarch had absolute power and his judges were loyal to him, it was necessary for the members of parliament to fight for liberty and independence and to include de iure these privileges in the constitution. However, in the second case after the death of the monarch, "the legislative body replaced the body of the king" taking over his inviolability.

In England, the execution of King Charles I in 1649, the first monarch to be put on trial and sentenced to death, marks the very beginning of legitimising the power of parliament to take action and to "assert the will of the political king against the will of the natural 
king" (Manow 2010, 27). As a result, this historical moment had great implications on the nature of constitutional and parliamentary procedures, which later on, on the eve of the Bill of Rights, shaped the modern meanings of the privilege of freedom of speech.

However, more than a century later, in France, the episode when Louis XVI was sentenced to death and publicly beheaded on the 21st January 1793 had much stronger political and constitutional effects. The decapitation of the king represented the end of the Ancien Régime and the birth of a new democratic system, in which the power was consisted of the citizens and their representatives. The revolution of 1789 , followed by the execution of the monarch, marked the transfer of sovereignty, where the attributes of the body politic of the Crown along with his inviolability and sanctity, were confiscated by the people. As Rousseau famously claimed, "the sovereign body of the people in its capacity as a legislator [...] is sacred and inviolable, as the Prince was in the earlier way of thinking. The inviolability previously enjoyed by the Prince now attached to the new bearer of sovereignty - corps sovereign. Consequently, the attributes of sacredness and inviolability of people as corps sovereign are transferred to its parliamentary representatives" (Manow $2010,50)$. The analysis of this entire process of embodying the sanctity and inviolability of the king in the people, who will become in this way sovereign, could be the subject of another inquiry, namely the parliamentarisation of divine grace, although this is not the scope of the current study.

On these accounts, we could now agree that the status of the members of parliament as being inviolable is symbolically an imitation determined by the embodiment of the king's sanctity towards the people. This kind of sanctity is afterwards transferred to the parliamentary representatives. The deputies or senators are immune from prosecution in the same way the prince or the king was before them; or, looking deep into history, they are inviolable as the tribunes in Roman times (Soulier 1966, 10-15). Under these conditions, Kantorowicz's doctrine of the king's two bodies and the process of transferring the divine rule of the monarch to the corps sovereign, represent a comprehensive answer to our initial question regarding the philosophical foundations of parliamentary immunity.

\section{The scope and practice of parliamentary immunity}

After carefully examining the origins of parliamentary immunity from its Latin foundations, pointing out the resemblances and differences between the English and French models and emphasising its philosophical conceptualisations that cleared up the wrong interpretations regarding the exclusive status of the members of parliament, it seems inevitable to also give a clear account of the practice of parliamentary immunity. Thus, in this part of the study, we will seek to explore the contribution of parliamentary immunity to democratic development, as well as its critics often brought by scholars and legal practitioners.

Even though the first meanings of immunity had nothing to do with democracy or other aspects of democratic life, in its entangled and long history, the concept, along with the Bill of Rights in England and the revolution of 1789 in France, started to acquire a diversity of conceptions with a direct impact on the independence and integrity of parliament. 
David McGee, in The Scope of Parliamentary Privilege, claims that "[...] immunity helps preserve Parliament's freedom from outside control and to give it and its members the legal tools and confidence they will need to perform their constitutional functions" (McGee 2004). Consequently, the scope is to strengthen and safeguard the Legislative and its members against any interference or obstruction from the part of the Executive, Judicial branches or other state institutions. This protection derives precisely from the doctrine and constitutional principle of the separation of powers, which is considered a pillar of the modern democratic government. James Madison, Alexander Hamilton, and John Jay, in their Federalist Papers, introduced a rough definition of the separation of powers, emphasising that "the accumulation of all power, legislative, executive and judicial, in the same hands, whether of one, a few, or many, and whether hereditary, self-appointed, or elective, may justly be pronounced the very definition of tyranny" (Madison 1987, 155). Hence, parliamentary privileges create the proper conditions for the separation of powers, with the purpose of allowing parliament and its members to freely conduct their activity.

Apart from reinforcing the separation of powers, parliamentary immunity allows, as was previously analysed, the transfer of sovereignty, from the king's personal rule to the people. This shift thus involves the disappearance of the monarch in its physical form as well as its institution, with parliament taking over representation of the national interest, a feature most-commonly found in all democratic societies. Popular sovereignty as a mark of democratic rule derives its meanings from the authority of the people who govern, within a legal framework, through their representatives, giving birth to a modern form of government, namely representative democracy. As John Stuart Mill argues in On Liberty, representatives freely elected by the citizens are the ones who have to secure and protect society from any threats (Mill 2001; Bobbio 2007). Thus, parliamentary immunity represents not only a link between sovereignty and representation, but translated into a normative approach, it is seen as a legal institution which assures the independence of parliament, but also its members.

However, parliamentary immunity, both in theory and in practice, being a sensitive aspect of parliamentary life in general, has recently been subject to criticism, especially regarding its relation with democratic values. Scholars often argue that the status of members of parliament in being immune from arrest from molestation is nothing more than a principle that strays from the normal democratic path and creates undemocratic practices. Critics brought both by academia and practitioners are also related to the fact that parliamentary immunity represents an instrument that allows the members of parliament to protect, as Anthony Down would say, their personal interest rather than the interest of the citizens (Wigley 2003). Probably, the most common negative interpretation that can be found in the literature dedicated to this concept is that parliamentarians are above the law and that parliamentary privileges are associated with acts of corruption. Simon Wigley offers an objective point of view, arguing that "parliamentary immunity undermine and to promote the process of democratization" (Wigley 2009). First, benefiting from such a legal regulation that protects them from any threats, parliamentarians are more inclined to follow their own political or economic interest. Second, the absence of parliamentary immunity could weaken the role of parliament by not allowing parliamentarians to do 
their duty. My claim is that parliamentary immunity brought, along with its history, great improvements to the democratic life in general and parliamentary life in particular. From the beginning it was designed to fight against the personal rule of the king and afterwards to maintain the independence and authority of parliament against the authority of the Executive and Judicial institutions. Regarding parliamentarians, the primary beneficiary of this privilege, the negative conceptions around parliamentary immunity are just matters of political and rhetorical perceptions. In fact, the scope and the practice of parliamentary immunity has remained the same, but the political realities determined other interpretations as a result of the dynamic political changes and post-democratic European environment. However, this is another story that needs to be told.

\section{Conclusions}

Using a variety of instruments and different intellectual studies and approaches specific to conceptual history, this present inquiry has analysed the different meanings and historical settings in which the concept of parliamentary immunity developed. The first outcome behind this particular endeavour was to exclude any misconceptions that were and still are attached to this concept in order to create a single and a coherent interpretation of parliamentary immunity. From its Latin understandings until the present day, our concept has suffered great changes due to strategic political moments in which both parliament and its members were engaged directly. The two models of immunity, the Anglo-Saxon form of privileges and its continental replica that first emerged in France after the revolution of 1789 , seems to have its origins and practices in the political struggle of parliament for independence against the authoritarian rule of the monarch. If the English model gradually acquired, from the 14th century, the characteristics that it still has today, French parliamentary immunity only took over some features previously developed in England and along with the revolutionary moment of 1789, drafted through the voice of Mirabeau and other legal scholars its own extended system of protection of members of parliament. A great deal of ambiguity also enclosed the nature of parliamentary immunity and many questions were directly attached to the legal and philosophical reasons regarding this exceptional status. In fact, parliamentary immunity with its two-folded features (inviolability and non-liability) is the embodiment, as Rousseau famously claimed, by the people through their representatives, of the king's sacredness and inviolability. Deconstructing Kantorowicz's theory of the king's two bodies and explaining the reasons behind the special status of parliamentarians represent the second important outcome of this study. Finally, the historical settings of parliamentary immunity also include prerequisites of the modern democratic state. That is to say, as we have already shown, parliamentary immunity is in close connection with the separation of powers, political representation, human rights, and the rule of law, which are primary features of the democratic formula. Evaluating this link between parliamentary immunity and democratic development is thus the third important outcome of this study. 


\section{References}

Bobbio, N. (1988). Liberalism and democracy. London: Verso.

Caesar, J. (1917). The Gallic War. Edwards H. J., trans. London: Harvard University Press.

Cicero, M. (1939) Philippics. Walter C. A., trans., London: Harvard University Press.

Collin, P. (2000). Dictionary of Medical Terms. London: A\&C Black.

Erskine, M. (2003). Treatise on the Law, Privileges, Proceedings and Usage of Parliament. London: LexisNexis.

Gillespie, J. (1997). The Age of Richard II. Cornwall: St. Martin's Press.

Griffith, G. (1997). 'Parliamentary Privilege: Use, Misuse and Proposals for Reform'. NSW Parliamentary Library Research Service. No. 4.

Griffith, G. (2007). 'Parliamentary Privilege: Major Developments and Current Issues'. NSW Parliamentary Library Research Service. No. 1.

Griffith, G. (2009). 'Parliamentary Privilege: First Principles and Recent Applications'. NSW Parliamentary Library Research Service Paper. No. 1.

Hardt, S. (2013). Parliamentary Immunity. A Comprehensive Study of the Systems of Parliamentary Immunity of the United Kingdom, France, and the Netherlands in a European Context. Portland: Intersetia

Hulst, M. (2000). The Parliamentary Mandate. A Global Comparative Study. Geneva: InterParliamentary Union Press.

Kantorowicz, E. (1997). The King's Two Bodies. Study in Medieval Political Theology. Princeton: Princeton University Press.

Livius, T. (1857). History of Rome. Spillan D. trans. London: Covent Garden.

Macreadie, R. \& Gardiner G. (2010). 'An introduction to parliamentary privilege'. Department of Parliamentary Service [online], No. 2, 2010. Available at <www. parliament.vic.gov.au/publications/...an-introduction.../download $>$.

Madison J., Hamilton A. \& Jay J.(1987). The Federalist papers. New York: Penguin Group.

Manin, B. (1997). The Principles of Representative Government. Cambridge: Cambridge University Press.

Mannow, P. (2010). In the King's Shadow. The Political Anatomy of Democratic Representation. Cambridge: Polity Press.

McGee, D. (2004). 'The scope of Parliamentary Privilege'. New Zeeland Law Journal. Vol. 84.

Mcgee, S. (2001). Rules on Parliamentary Immunity in the European Parliament and the Member States of European Union. Belgium: ECPRD, Belgium, 2001.

Mill, J. S. (2001). On Liberty. Kitchener: Batoche Books.

Palonen, K. (2002). 'The History of Concepts as a Style of Political Theorizing: Quentin Skinner's and Reinhart Koselleck's Subversion of Normative Political Theory'. European Journal of Political Theory. Vol. 1, pp. 91-106.

Pollard, A. F. (1920). The Evolution of Parliament. London: Longmans, Green.

Rein, A. (2001). Le Grand Robert de La Langue Francaise. Paris: Dictionnaires Le Robert. 
Richter, M. (1995). The History of Political and Social Concepts. A Critical Introduction. New York and Oxford: Oxford University Press.

Report on the Scope and Lifting of Parliamentary immunity, Venice Commission. Available at < http://www.venice.coe.int/webforms/documents/default.aspx?pdffile=CDL-AD(2014)011-e>.

Sartori, G. (1970). 'Concept Misformation in Comparative Politics'. The American Political Science Review. Vol. 64, No. 4, pp. 1033-1053.

Schmitt, C. (2008). The Crisis of Parliamentary Democracy. Cambridge: MIT Press.

Smith, W. (1882). Dictionary of Greek and Roman Antiquities. New York: Harper and Brothers Publishers.

Soulier, G. (1966). L'inviolabilité parlementaire en droit droit français. Paris: Pichon/ Durand-Auzias.

Suetonius, G. (1914). The Lives of Caesars. Rolfe J. C. trans. London: Harvard University Press.

Steinberger, P. (1993). The Concept of Political Judgement. Chicago and London: The University of Chicago Press.

Tocqueville, A. (1856). The Old Regime and the Revolution. John Bonne, J. trans. New York: Harper and Bothers Publishers.

Wigley, S. (2003). 'Parliamentary Immunity: Protecting democracy or protecting corruption?' The Journal of Political Philosophy. Vol. 11, No. 1, pp. 23-40.

Wigley, S. (2009). 'Parliamentary Immunity in Democratizing Countries: The Case of Turkey'. Human Rights Quarterly. Available at <http://wigley.bilkent.edu.tr/ SimonWigleyImmunityHRQ.pdf > 